\title{
O que é a montagem num filme?
}

Mirella Martinelli

Trabalha em cinema desde 1982. É montadora, editora de som, roteirista, diretora, produtora e professora. Em 1997, foi premiada pela American Cinema Editors Association, em Hollywood. E-mail: mirellamica@yahoo.com

Meu interesse por fazer cinema surgiu na adolescência, no final dos anos 1970, quando eu ia ao cinema de três a quatro vezes por semana. Estudava no Colégio Equipe, que naquela época se localizava no bairro do Bexiga. O cine Bijou, na praça Roosevelt, fechava os olhos para o fato de que não tínhamos ainda 18 anos, e admitia a nós, colegiais de 15, 16 e 17 anos, em qualquer uma de suas duas salinhas onde maravilhas do cinema eram apresentadas. Saíamos da aula e íamos às sessões vespertinas assistir a pérolas como $\mathrm{O}$ sétimo selo ${ }^{1}$, Gritos e sussurros ${ }^{2}$, Roma, cidade aberta ${ }^{3}$, Repulsa ao sexo ${ }^{4}$, Easy rider $^{5}$, Tempos modernos ${ }^{6}$, e outros filmes que marcaram nossa visão de mundo e fazem parte da minha formação como cineasta.

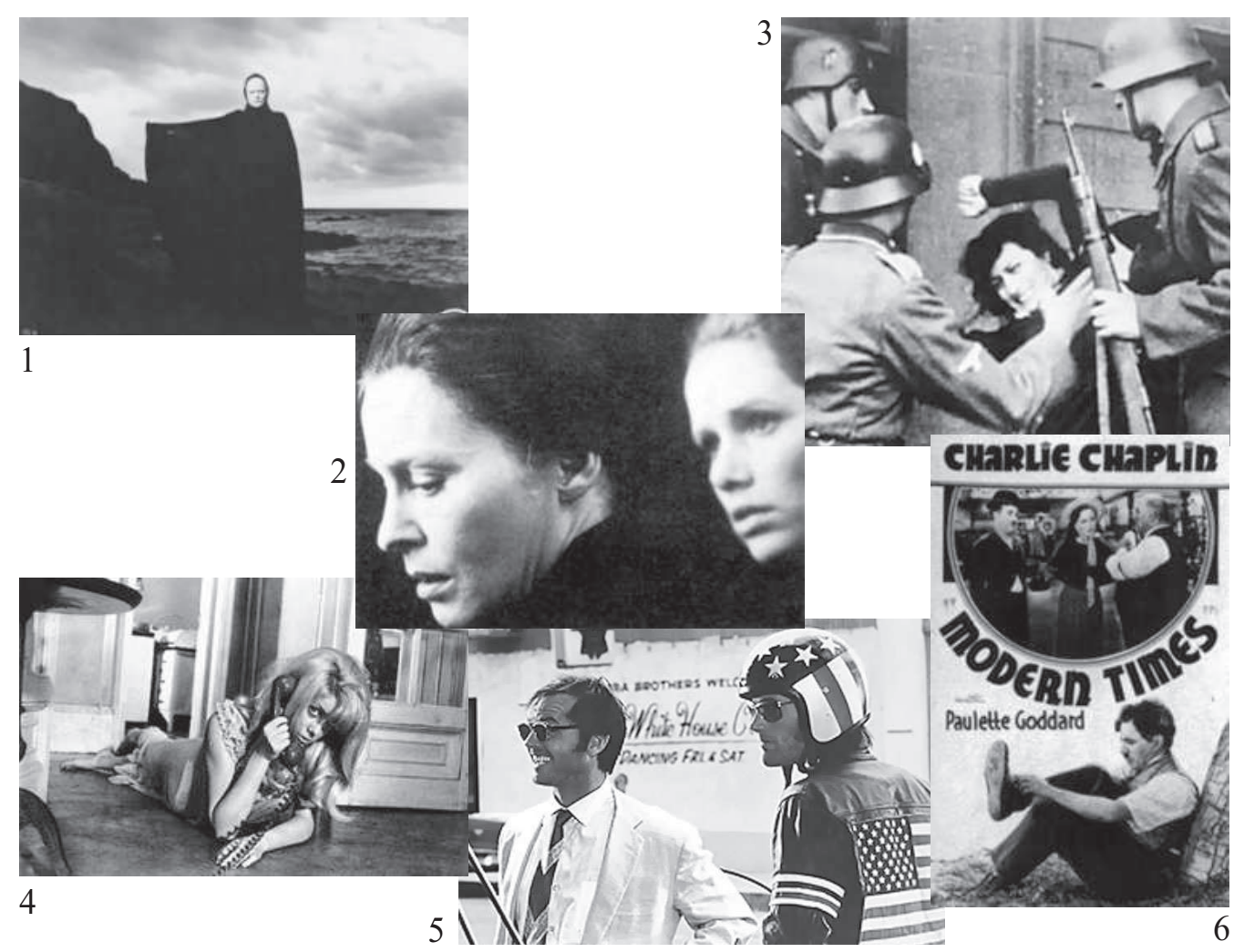

O sétimo selo, Gritos e sussurros, Roma, cidade aberta, Repulsa ao sexo, Easy rider, Tempos modernos: filmes que marcaram época.

1. O SÉTIMO selo (Det Sjunde Inseglet). Direção: Ingmar Bergman. Suécia, 1956. (100 min.)

2. GRITOS e sussurros (Viskningar Och Rop). Direção: Ingmar Bergman. Suécia, 1972. (90 min.)

3. ROMA, cidade aberta (Città Aperta). Direção: Roberto Rossellini. Itália, 1945. (98 min.)

4. REPULSA ao sexo (Repulsion). Direção: Roman Polanski. Inglaterra, 1965. (105 min.)

5. EASY rider (Sem destino). Direção: Dennis Hopper. Estados Unidos, 1969 (95 min.)

6. TEMPOS modernos (Modern times). Direção: Charles Chaplin. Estados Unidos, 1936. (87 min.) 
comunicação \& educação • Ano XI • Número 1 • jan/abr 2006

Naquela época, também eram organizadas sessões de cinema no Equipe, onde cheguei a ver Também não se matam cavalos? ${ }^{7}$ e - talvez tenha sido lá - ao então proibido Encouraçado Potemkim ${ }^{8}$. O cinema era consistente. Os efeitos especiais, quando chegavam a existir, não importavam. $\mathrm{O}$ que importava era $\mathrm{o}$ drama humano e social.

Decidi prestar vestibular para Cinema. Eu também queria me expressar, dizer coisas através da sucessão de imagens, de cenas, por meio do drama de personagens fictícios. Entrei na $\mathrm{ECA}^{9}$ e logo me interessei por montagem.

Mas que é isso: montagem?

Quando assistimos a um filme, é comum reparar na história, nos atores e na fotografia; afinal, é o que está mais em evidência. Até mesmo na direção não se repara muito, talvez por ser difícil, para quem não é profissional da área, delimitar o que é a direção num filme. Montagem, então, nem se fala! A maioria das pessoas, até os cinéfilos, não tem lá muita idéia do que seja montagem. E por que teriam? É mesmo uma idéia um pouco abstrata. Mas a montagem influencia tanto no resultado final de um filme, que é, de fato, interessante conhecer essa atividade.

Até hoje, 22 anos depois que comecei a montar, é engraçado como ainda embatuco quando as pessoas perguntam minha profissão. "Sou montadora". Em geral me olham com cara de ponto de interrogação. "De cinema...", acrescento, na esperança de não parecer que trabalho numa fábrica que monta carros ou algo assim. Daí passam a achar que sou a produtora, quem "monta" aquele circo todo para o diretor filmar. "Não. Montagem é... é meio parecido com ser editora... de vídeo, sabe?”. É mais ou menos isso. Talvez a idéia mais próxima à montagem que pessoas de outras áreas possam ter seja o conceito de edição. Então vamos começar por aí.

O dicionário Houaiss ${ }^{10}$ tem uma definição boa de edição no contexto de cinema, rádio e televisão: "Seleção e coordenação de materiais filmados ou gravados para elaboração de um filme ou programa". Para montagem, o mesmo dicionário diz: "Processo pelo qual o montador seleciona as cenas de uma

7. TAMBÉM não se matam cavalos? / A noite dos desesperados (The shoot horses / They shoot horses, don't they?). Direção: Sydney Pollack. Estados Unidos, 1969. (120 min.)

8. ENCOURAÇADO Potemkim (Bronenosets Potyomkin). Direção: Sergei Eisenstein. Rússia, 1925. (74 min.)

9. Escola de Comunicações e Artes da Universidade de São Paulo.

10. HOUAISS, Antonio. Dicionário Houaiss da Língua Portuguesa. Rio de Janeiro: Objetiva, 2004. filmagem, após o seu término, unindo-as em seqüência para formar um filme". $\mathrm{O}$ interessante é que, apesar de eu preferir me denominar montadora (do que editora) - e depois explico o porquê -, a definição de edição do Houaiss é a que mais se aproxima do trabalho dos montadores de cinema. Isto porque os termos coordenação e materiais filmados ou gravados estão presentes na definição. Já a explicação do mesmo dicionário para montagem peca por falar em seleção de cenas e unir em seqüência. Essa diferença é fundamental.

Quando falamos em materiais filmados ou gravados, queremos dizer tudo o que foi captado de imagem e som. Pode ser apenas um segundo, até um fotograma de imagem (a unidade mínima do material filmado: uma das 24 fotos que a câmera de cinema bate por segundo); pode ser apenas um som, uma frase preciosa de algum depoente, uma nota musical que se estende ao final de uma música gravada ao vivo, o ruído de um colchão de molas velho que guincha quando alguém senta nele... Tudo isso é material para o montador. 
Não trabalhamos apenas com a cena: aliás, nós, montadores, é que construímos as cenas.

Quando falamos em unir em seqüência, pode parecer que o montador apenas põe na ordem o material filmado. Fazemos isso também, mas se pensarmos em "coordenar" os materiais, nós nos aproximaremos mais da idéia do que a montagem realmente faz.

Para dar um breve exemplo, cito um filme ficcional que montei recentemente: Contra todos ${ }^{11}$ dirigido por Roberto Moreira. Apesar de o roteiro original ter muitas virtudes no tocante à densidade que conferia aos personagens - e, pelo desenrolar da trama, no desvendar de seres mais profundos por trás de máscaras sociais -, havia uma ordem em que a história era contada que julgamos não funcionar quando o filme teve sua primeira montagem (primeiro corte). Assim, mudamos radicalmente a ordem em que as cenas seriam apresentadas ao espectador, indicamos as que seriam suprimidas e até quais precisavam ainda ser filmadas para que o filme chegasse à forma final.

A montagem coordenou as cenas e planos diferentemente do previsto no roteiro. É um exemplo de como a ordem de apresentá-los, mesmo havendo história - fatos que se sucedem, que causam con-

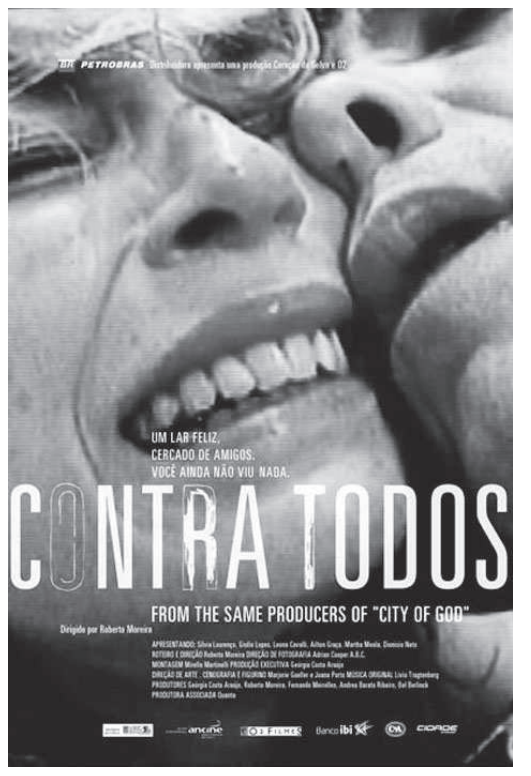

Pôster de divulgação do filme Contra todos. seqüências, que geram outros fatos e reações nos personagens -, mudou radicalmente na montagem e o filme ganhou outro ritmo, deu outra compreensão a determinados personagens e ações, causando nos espectadores impacto diferente do que seria se a ordem do roteiro tivesse sido obedecida mais fielmente.

Quando fazemos a montagem de um documentário, essa liberdade de coordenação é praticamente ilimitada.

Proponho ao leitor entender como se dá o trabalho de montar para que posteriormente possa assistir a um filme conseguindo enxergar nele a montagem. Para tal é preciso esclarecer três pontos básicos:

\section{1) O que é um plano}

Entende-se por plano a imagem captada desde o momento em que a câmera é ligada e começa a filmar, até ser desligada. Assim, por exemplo, o rosto de Fernanda Montenegro em Central do Brasil ${ }^{12}$, olhando para o menino que está a seu lado no banco do ônibus, é um plano - um trecho do plano filmado originalmente. O rosto do menino ocupando a cena enquanto ele pede a ela que escreva uma carta é outro plano - pode ser um close. Quando vemos um ladrão correr para fora do prédio da estação junto aos trilhos de trem, temos um plano geral da estação. Todos esses planos foram filmados em disparos de câmera separados, e, em geral, muito mais longos do que o

11. CONTRA todos. Direção: Roberto Moreira. Montagem: Mirella Martinelli. Brasil, 2004. (95 min.). Site oficial: <www. contratodos.com.br $>$.

12. CENTRAL do Brasil. Direção: Walter Salles. Brasil, 1998. (112 min.). 


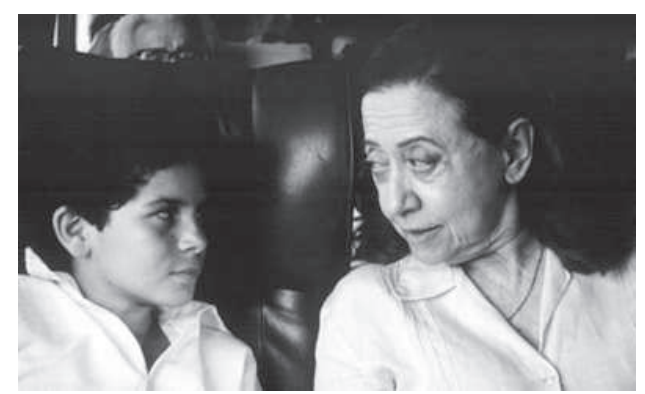

Exemplo de um plano no filme Central do Brasil.

trecho que acaba por ficar na montagem final do filme.

Take (ou tomada) é a palavra que usamos para designar a repetição do mesmo plano para uma melhor interpretação do ator, ou melhor movimento de câmera, ou qualquer motivo pelo qual o diretor não considerou o primeiro take bom. É raríssimo que num filme de ficção se faça apenas um take de um plano. Geralmente há, no mínimo, três, mas pode haver sete, dez ou quantos o diretor achar necessário para obter um resultado satisfatório.

\section{2) O que é uma cena ou seqüência}

É uma situação que ocorre num espaço e num tempo determinados. Por exemplo, a cena em A cor do paraíso ${ }^{13}$ (filme iraniano espetacular; se não viu, pegue na locadora!) em que o pai busca seu filho cego na escola. O pai observa o filho de longe, hesita em se aproximar. Finalmente se aproxima e os dois se tocam. Vão embora juntos. Na cena seguinte, os dois personagens são vistos caminhando na rua. Como o espaço já é outro, é outra a cena (no caso, a cena da rua é uma cena de passagem, pois não se desenrola ação dramática). Podemos também ver o personagem em seu quarto, à luz do dia, arrumando seu armário. Novo corte, para o mesmo quarto: noite, personagem

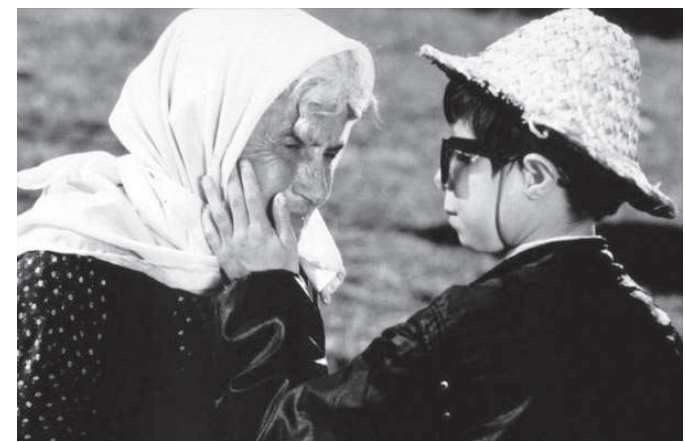

A cor do paraíso. dormindo - já é outra cena, pois houve passagem de tempo.

13. A COR do paraíso (Rang-e Khoda). Direção: Majid Majidi. Irã, 1999. (90 min.)
A montagem passo a passo 
Uma vez compreendido isso, podemos entender quais são as tarefas da montagem, olhando para a atividade de forma mais ou menos cronológica. A montagem começa quando o montador recebe o material filmado. A quantidade de material varia muito. Desde dez, 20 horas do que chamamos de material bruto para um longa filmado em película (material caro, pois são rolos de filme de emulsão de sais de prata que precisam ser revelados em laboratório), até 50, 100 horas de material bruto; ou até mais, quando se trata de filme que utilizou o vídeo como suporte de captação (fitas de vídeo são incomparavelmente mais baratas que rolos de filme).

Atualmente, vários filmes, principalmente documentários, usam uma mistura dos dois materiais. Podem ser filmadas determinadas imagens com película, e as entrevistas gravadas em vídeo, por exemplo. Daí já dá para ter alguma idéia de quão determinante é o trabalho da montagem.

Minha última experiência de montagem de longa documental foi o filme Extremo Sul ${ }^{14}$, de Mônica Schmiedt e Sylvestre Campe. Tínhamos 100 horas de material bruto para montar um produto final de 90 minutos. Seleção é uma parte importante de nossa atividade.

O advento da montagem digital já tem uns dez anos no Brasil. Em 1995, montei meu longa Terra do $\operatorname{mar}^{15}$ fazendo uso da tecnologia digital. Foi um dos primeiros filmes no Brasil a ser completado sem um copião ${ }^{16}$ em película. O negativo foi montado diretamente a partir de uma lista de cortes fornecida pelo software de edição. Hoje, quase todos os filmes são montados inteiramente no computador e só são feitas cópias em película para a distribuição comercial em cinemas. Assim, o material que o montador recebe está em fitas de vídeo digital que serão capturadas para os hard discs do computador (ou HDs externos), trabalho feito pelo assistente de montagem. Ao ser capturado, o material será organizado da forma que o montador solicitar.

Quando se trata de um filme ficcional, prefiro a organização por seqüências (ou cenas), isto é, cada cena tem sua pasta com todos os planos referentes àquela seqüência. Quando se trata de um documentário, aí varia muito. Mas, geralmente, a preferência é a organização por assuntos. Exemplo de Terra do mar: pasta com todos os planos referentes à pesca feita em alto-mar; pasta dos planos da Lua; pasta dos planos de captura de caranguejo no mangue etc. Moviola: máquina utilizada para o seqüenciamento dos planos em película antes do advento da montagem digital.

O material tem de ser ordenado de alguma forma. Quando a montagem ainda
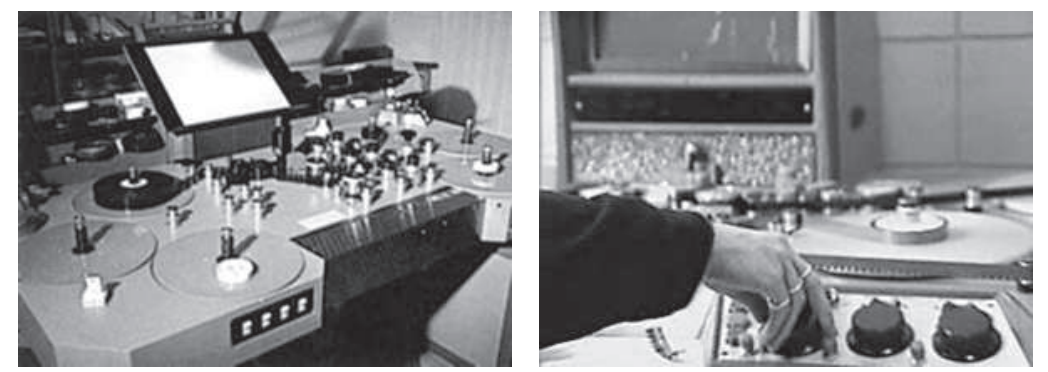

era feita em película, naquela máquina cheia de rodas dentadas chamada moviola,

14. EXTREMO Sul. Documentário. Direção: Mônica Schmiedt e Sylvestre Campe. Montagem: Mirella Martinelli e Kiko Ferraz. Brasil, 2005. (92 min.). Site oficial: <www.extremosul. com>.

15. TERRA do mar. Direção: Mirella Martinelli e Eduardo Caron. Brasil, 1997. (81 min.).

16. Cópia de trabalho do filme impresso, com as cenas cortadas e unidas na ordem preferida pelo montador. É a primeira cópia positiva feita com o negativo de um filme. 
a ordenação do material era absolutamente imprescindível, pois este só poderia ser assistido se os planos estivessem emendados um após o outro, em grandes rolos que iam se desenrolando, passando por uma pequena projeção, e se enrolando do outro lado da máquina. Hoje, a ordenação não é mais obrigatória. Afinal, usando o computador, pode-se clicar em qualquer plano e assisti-lo na ordem que bem quiser, instantaneamente. Portanto, a organização do material bruto vai depender muito do estilo de trabalho de cada montador e do projeto em questão. No caso da montagem de Contra todos, pedi aos assistentes que ordenassem, em cada pasta da seqüência, os planos de acordo com a ordem proposta no roteiro para cada cena, com todos os seus takes.

No caso de Extremo Sul, eu e meu co-montador ordenamos os planos dentro da pasta de cada assunto simplesmente na ordem que haviam sido filmados. A ordem cronológica de filmagem, nesse caso específico, foi importantíssima. É um filme documental sobre uma expedição de alpinistas, e o desenrolar dos fatos, de acordo com a passagem dos dias e os eventos da natureza, foi especialmente determinante no projeto.

\section{A ARTE DA HISTÓRIA}

Agora é que a porca torce o rabo. E que o negócio começa a ficar interessante também. Porque até então falamos mais de técnica. Aqui começa a arte.

O que fazer depois que o material bruto está captado e ordenado depende da particularidade de cada projeto e do jeito de trabalhar de cada montador e de cada diretor. A dupla montador-diretor precisa ter uma boa afinidade e concordar com métodos de trabalho. Como cada caso é tão único e particular, só posso continuar por via de exemplos. Utilizarei os mesmos até aqui: Contra todos e Extremo Sul por serem dois longas-metragens recentes (2004 e 2005, respectivamente), ambos muito competentes (portanto, bons filmes para o leitor mais interessado assistir e então visualizar melhor a explanação) e bastante diferentes entre si, a começar pelo fato de o primeiro ser uma ficção e o segundo, um documentário.

Em Contra todos, o diretor Roberto Moreira e eu optamos por escolher, juntos, quais os melhores takes a serem utilizados. Assim, assistíamos à cena completa, com todos os planos e todos os takes, na ordem do desenrolar da ação e, juntos, selecionávamos a melhor interpretação. Contra todos é um filme com

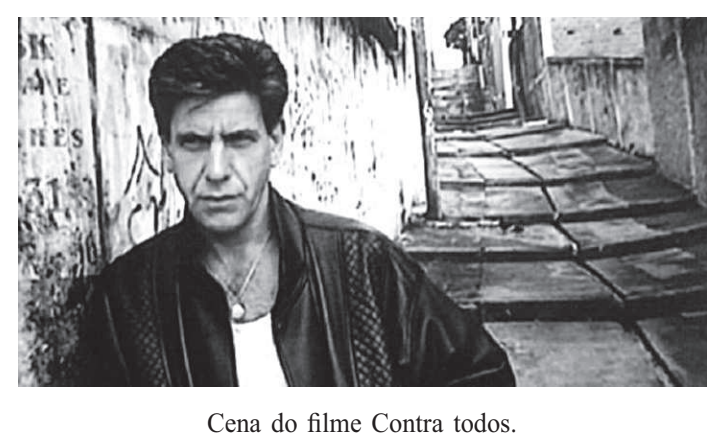

muito movimento de câmera, principalmente de câmera na mão; raros são os planos de câmera fixa no tripé. Assim, o movimento também era observado, mas nossa escolha se pautou muito mais pela excelência da interpretação do que pela eficácia do movimento. Dois motivos foram preponderantes: nesse filme, a interpretação realista 
(rara nos filmes brasileiros até então) foi muito buscada e conseguida magistralmente por meio de vários trabalhos com os atores. Escolher o take onde se pudesse crer totalmente na veracidade daquele personagem era fundamental para dar continuidade a esse esforço de direção para o naturalismo; o outro fato foi que a câmera (operada por Adrian Cooper) estava, via de regra, excelente, de forma que tivemos a liberdade de escolher os takes cuja interpretação mais gostávamos.

Depois da seleção, Roberto me deixava só para que eu fizesse as propostas e voltava dali alguns dias para ver as cenas montadas. O que quer dizer cenas montadas? Eu escolhia o ponto de corte, isto é, até que momento usaria um plano e a partir de qual utilizaria outro. Temos, por exemplo, a cena de Teodoro e Waldomiro conversando no carro. Quando vou usar Teodoro falando e em que momento passo a mostrar Waldomiro ouvindo? Quando é mais importante que a fala seja dita na tela pelo personagem e quando a reação do ouvinte é mais importante de estar sendo observada? Quando é o momento de usar um plano no qual os dois apareçam juntos? Além do diálogo, que outras ações me pautam para essas escolhas? Quando é preferível usar um plano bem fechado, que mostre só os olhos do personagem, e quando é melhor mostrar seu rosto todo? Em que momento revelar onde está esse carro (plano geral) e o movimento que ocorre do lado de fora? Quando interromper essa cena do filme, cortando para outra? Ou, será que, em vez de cortar, faço uma fade-out (escurecimento) para terminar a cena? Esses são alguns exemplos das inúmeras possibilidades que a montagem oferece.

Como utilizamos a montagem digital, posso fazer mais de uma opção (o que não era possível na montagem em película, que exigia que se desmontasse uma opção para montar outra, uma vez que os cortes eram feitos de forma física sobre os planos). No caso de Contra todos, tinha sempre pelo menos duas opções para mostrar ao diretor quando ele voltava à sala de montagem. Ele escolhia uma ou criávamos outra montagem a partir de meus primeiros estudos e com as observações dele. Assim, fomos trabalhando as cenas e montando o filme em sua primeira ordem, o que chamamos de primeiro corte. Em Contra todos, o primeiro corte tinha duas horas e meia de duração.

Em um documentário, as coisas são bem mais complexas. Em Extremo Sul, a primeira versão do filme - vamos dizer assim - tinha três horas e meia e preferi chamá-la de estrutura. Como sabemos que as palavras têm, sim, grande importância, explico o porquê. Fazer documentário é uma caixinha de surpresas. Não sabemos se aquilo que nos propomos a documentar vai acontecer mais ou menos de acordo com o previsto. No caso de Extremo Sul, não aconteceu. O roteiro de filmagem foi seguido bastante fielmente durante o começo da expedição dos cinco alpinistas que estavam sendo documentados ao realizar uma expedição para tentar atingir o cume de uma montanha gelada na Terra do Fogo ${ }^{17}$.

Porém, quando o grupo deixou o continente, atravessou o estreito de Magalhães e acampou na ilha Grande, na Terra do Fogo, as coisas se modificaram. A natureza humana trouxe surpresas que os documentaristas se esforçaram por captar da melhor forma possível. Mas, longe de ser o previsto, quando fui convidada a montar o filme, a diretora me disse: "Não sei se tenho um filme aí".

17. A Terra do Fogo é um arquipélago na extremidade Sul da América do Sul, formado por uma ilha principal e um grupo de ilhas menores. Está separado do continente pelo estreito de Magalhães. Em 1881, o território foi dividido entre a Argentina e o Chile. A montanha escolhida pelos alpinistas é o monte Sarmiento e fica no território do Chile, entre os oceanos Atlântico e Pacífico. 
Já dá para perceber, caro leitor, que em Extremo Sul meu papel foi radicalmente diferente de em Contra todos?

Fiz o visionamento do material bruto de Extremo Sul em fitas de VHS e seguiram-se dias de reuniões das quais participaram eu, meu colega co-montador, Kiko Ferraz, os dois diretores do filme, Mônica Schmiedt e Sylvestre Campe, e o roteirista (que havia elaborado o roteiro de filmagem). Tentávamos entender o que havia se passado naquela expedição tão conturbada e que filme faríamos a esse respeito. Quem era cada um daqueles alpinistas? Por que tinham tomado determinadas decisões? Um filme que seria de aventura tinha se transformado em que gênero? Ou não havia mais gênero e, sim, um filme completamente original, sobre uma situação bizarra? O que era mais importante ressaltar das 100 horas filmadas?

Nessas reuniões, sugeri verbalmente uma estrutura que foi pré-aprovada pelos diretores como uma tentativa de colocar em pé esse filme que ninguém tinha muita idéia do que seria. Ela consistia em começar a mostrar a expedição pela travessia do perigoso estreito de Magalhães, durante a qual seriam apresentados, em flashback, os cinco protagonistas e os motivos que os levaram a tentar atingir o cume do monte Sarmiento, uma montanha tão difícil e tão pouco explorada. Depois, iríamos obedecer à ordem cronológica dos acontecimentos: montagem do acampamento-base, montagem do acampamento $1 \mathrm{e}$ os fatos que se sucederam até o último dia de expedição.

Quando Kiko e eu, a sós na sala de montagem, começamos a trabalhar essa primeira estrutura, fomos aos poucos percebendo que não estava bem claro para nós o que havia ocorrido em determinadas passagens.

Por mais que recorrêssemos à memória dos que tinham estado presentes na expedição (a equipe de filmagem), havia muita coisa que eles mesmos não sabiam, quer por estarem em outro acampamento, quer porque os motivos reais faziam parte

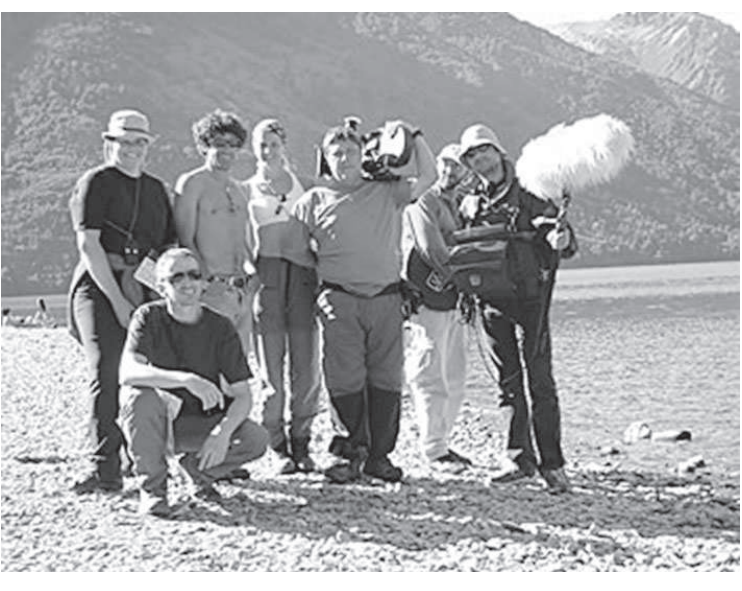

Equipe de filmagem de Extremo Sul. do mundo interior de cada alpinista e não eram tão facilmente revelados nem para as câmeras, nem para os outros integrantes da expedição. Mais do que isso, em busca de relatar aquilo que pudéssemos julgar mais próximo da verdade do que havia se passado na montanha, nós, montadores, consideramos que os pontos de vista dos próprios diretores poderiam estar contaminados pelos acontecimentos da expedição e nem sempre retratar o lado dos alpinistas. Saímos à procura de materiais filmados que pudessem evidenciar, ou pelo menos indicar, fatos e sentimentos não expressos. Aí começou um verdadeiro trabalho de detetive.

$\mathrm{Eu}$ anotava num caderno o que havia se passado desde que o grupo pôs 
os pés no sopé da montanha, e o que tínhamos de cada dia: material em película filmado pela câmera oficial, material em vídeo filmado pela equipe principal, material em vídeo filmado por um dos alpinistas e, finalmente, o making off ${ }^{18}$.

Assim, acabamos por escarafunchar um material que nem seria utilizado no filme em si, mas para o material promocional. Também vasculhamos materiais de dois anos antes da filmagem, quando parte do grupo havia feito uma viagem de reconhecimento à montanha.

Fomos compondo assim nossa idéia do que havia se passado lá, encontrando frases muito reveladoras no making off, em depoimentos informais, em reuniões entre alpinistas e equipe de filmagem, nas quais ninguém prestou atenção ao mocinho que empunhava sua modesta camereta de vídeo, e cujo material acabou sendo de extrema valia, a despeito de sua baixa qualidade técnica. Dia após dia, íamos avançando, cada vez mais com uma noção bem acurada do que tínhamos para contar, e de coisas que apenas podíamos depreender sem poder mostrá-las ao espectador, pois não haviam sido gravadas ou filmadas. No ápice da crise ocorrida na expedição, um único plano de poucos segundos foi filmado pela câmera do alpinista principal: o pano do interior de sua barraca. No grau de imersão em que estávamos naquele material, sabíamos muito bem o que aquilo significava, mas como contar para o espectador sem ele ter de assistir a 100 horas de filmagens?

Outras vezes, literalmente, pulávamos da cadeira e gritávamos, exultantes, quando encontrávamos pérolas, como, por exemplo, um rápido reflexo nos óculos espelhados de um dos alpinistas, que revelava o que havia por trás das câmeras. Este processo demorou muito, muito tempo. Meses depois de minha contratação, estávamos prontos a mostrar aos diretores nossa primeira e surpreendente estrutura. Para não deixar por menos, Kiko comentou que minha montagem da cena final carecia de música para dar a intenção da emoção desejada. A referência estava em minha mente. Procuramos na internet a música que eu achava que ia dar o clima, aplicamos sobre a cena final e assistimos juntos. Kiko se virou para mim e disse: "Tu vai fazer a alemoa chorar", referindo-se à nossa querida diretora, de descendência alemã. Tentando disfarçar as lágrimas que escorriam dos meus olhos, respondi: "Que nada... a alemoa não é manteiga derretida como eu". No dia seguinte, eu que pensava que ela era mais dura na queda, vi para que serve uma caixa de lenço de papel.

\section{E DEPOIS QUE O FILME ESTÁ ESTRUTURADO?}

Daí muda tudo, claro! Depois que está estruturado o primeiro corte, passamos ao segundo corte. Agora, assistindo a uma proposta de filme, fica bem mais fácil ver os problemas e aventar as soluções.

No caso de Contra todos, a apresen-

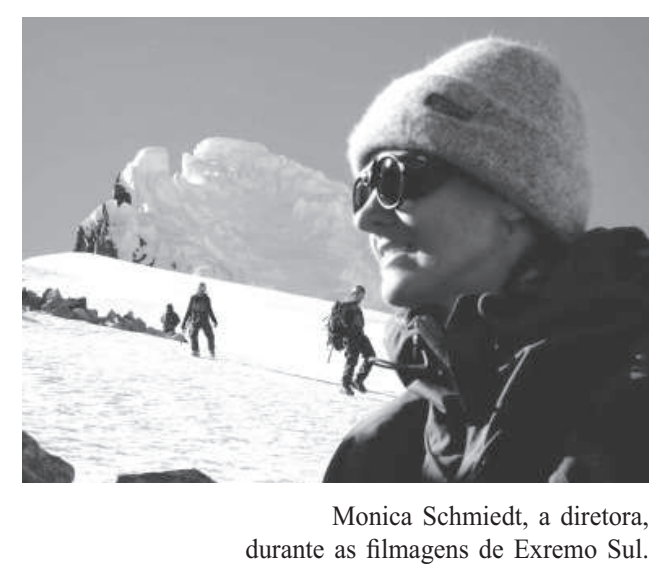

18. Filmagem e acompanhamento do processo de produção e os bastidores de um filme para o cinema ou outro meio, além de entrevistas com os artistas e diretores. 
tação do primeiro corte para a produtora do filme (exibida no monitor de TV, com a imagem vinda diretamente do software de edição) veio corroborar uma idéia que eu tinha desde a leitura do roteiro: era preciso contar aquela história quase toda em ordem cronológica, com pequenas exceções no fim do filme, diferentemente do proposto no roteiro, que era um quebra-cabeça para o espectador. Essa coisa de embaralhar a história funciona para alguns filmes (como, por exemplo, acho que funciona muito bem em 21 gramas $^{19}$ ), mas no caso de Contra todos, diluía a força e a veracidade de muitas reações e de muitas motivações dos personagens. Além disso, atrasava a apresentação de fatos importantes e adiantava revelações que levariam o espectador a um pico de emoções muito no início do filme, que não era o desejado em termos de estrutura dramática. Assim, o segundo corte de Contra todos mudou a ordem de praticamente todas as cenas, com todas as implicações dessa mudança. Também tiramos do filme algumas cenas inteiras.

Em Extremo Sul, no segundo corte decidimos não começar o filme pela travessia de barco, e, sim, por uma etapa anterior da expedição, além de cortarmos 40 minutos, diminuindo a duração para duas horas e meia. Diversas cenas foram modificadas, tentando buscar sempre maior clareza na exposição dos fatos, bem como recuperar as emoções sentidas a cada etapa da expedição.

O segundo, terceiro e todos os cortes que se seguem até o final são, na maioria

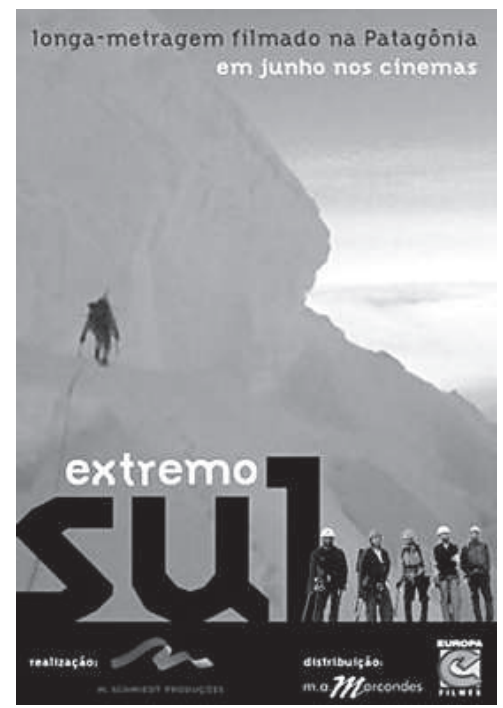

Pôster de divulgação do filme Extremo Sul. das vezes - e é aconselhável fazê-lo -, acompanhados de sessões-teste. Algumas pessoas são convidadas a assistir ao filme ainda em montagem. É imprescindível ouvir a impressão de quem não está em contato com o material todos os dias, não sabe como aquela história vai terminar nem conhece as intenções que orientam a montagem. Com essas sessões, podemos perceber que certas coisas que nos pareciam bem explicadas podem estar obscuras e que outros assuntos estão por demais insistentes aos olhos dos espectadores. Aparece que determinada cena que adoramos é chata para a maioria dos outros. Por outro lado, podemos confirmar que certa cena está superemocionante, que o cerne do que queremos comunicar está sendo realmente transmitido, que o ritmo está bom e que ninguém dorme na cadeira etc. Também é preciso selecionar quem se convida para essas sessões e saber ouvir sem o compromisso de satisfazer a gregos e troianos.

Se pensarmos nas inúmeras possibilidades que estão envolvidas na montagem, temos sempre a chance de fazer um filme totalmente novo, bem como apenas mexer em detalhes ou trabalhar num meio-termo. Tudo vai depender da reação de nossos públicos-teste e do grau de satisfação que o diretor e o 


\section{O CORTE FINAL}

No Brasil, basicamente, quem tem a palavra final é o diretor. Isso tem mudado e, cada vez mais, o produtor tem opinado (coisa que também já havia acontecido em épocas passadas, em grandes produções). Na etapa do corte final, é quando se decide exatamente o tamanho de cada plano (e, às vezes, ficamos a discutir por dois fotogramas, um doze avos de segundo!), se, definitivamente, um plano entra ou sai do filme, se o escurecimento ou clareamento é de um, dois, três segundos, dois segundos e meio... e tudo o mais que tem de ser decidido. Após esse corte, não há mais mudanças na imagem: passa-se à etapa de edição de som e mixagem.

O trabalho do dia-a-dia de montagem é um trabalho muuuuito solitário do montador, com mais ou menos visitas do diretor - dependendo do estilo de cada um e de eventuais projeções para o produtor. O montador chega a ser um co-diretor, pois a montagem é a segunda direção de um filme.

Agora que o leitor conhece um pouco sobre o que é a montagem, se por acaso encontrar meu longa Terra do mar (que é sempre exibido na TV Cultura, por exemplo, e pode ser achado em algumas locadoras), imagine que aquele plano da lua cheia com as nuvens passando na frente poderia estar em qualquer parte do filme. Imagine que eu poderia ter optado por mostrar o mar comendo a terra e acabando com vilarejos no começo do filme e deixar a pesca do camarão mais para o fim. Imagine que aquele plano filmado da água, que mostra uma ilha de mangue, poderia ter sido substituído por um outro onde vemos a ilha mais de longe. Ou mais de perto. Que o plano poderia ser mais curto ou mais longo. Que a música inicial poderia não ter letra... e que diferença isso faria no entendimento de todo o filme? Imagine quantas são as opções.

Para fazer uma idéia vaga, pois isso é muito variável, um longa pode ter por volta de 600 planos (um filme de ritmo mais lento) ou 1.200 planos (ritmo rápido). A cada plano, a cada corte, a cada cena estão envolvidas várias decisões. Por isso é que gosto de me denominar "montadora" e não editora. O montador precisa de tempo para assistir com calma ao material bruto, para experimentar, discutir com o diretor e outros envolvidos, para ir chegando pouco a pouco a um corte final. Para mudar toda a estrutura antes pensada, se for o caso. Demorei nove meses montando Extremo Sul. No outro filme, Contra todos, a montagem consumiu cinco meses. É um trabalho de paciência.

A idéia que faço de edição é uma coisa mais rápida, mais ligada aos cortes em si, do que a toda a estrutura dramática de uma história. Soa para mim como algo mais técnico e prático. Ser montador é fazer o filme com o diretor. Montagem, para mim, traz a

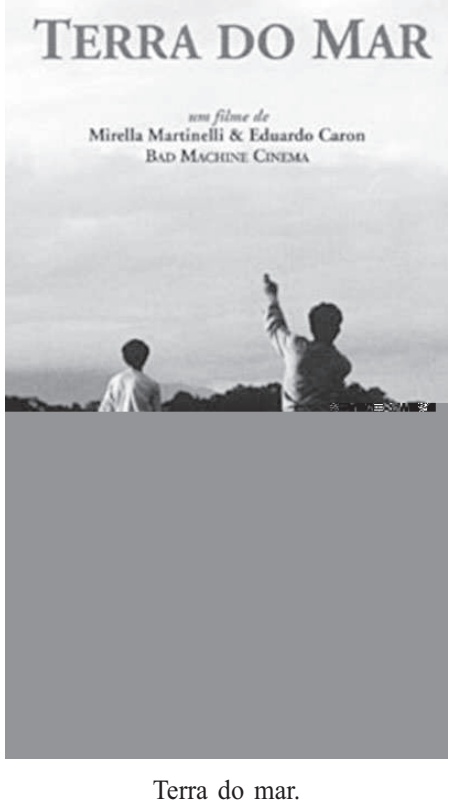


noção de compromisso artístico, que é o que me levou a fazer Cinema.

Agora assista a qualquer longa. Observe os planos. Quando começam, onde terminam. O que vem depois, como se abre o filme, como se fecha uma cena. Solte a criatividade e imagine que outros planos ou takes poderiam existir. Que engraçado deve ter sido filmar o ator caindo na piscina de terno, e quantos outros ternos seriam necessários para fazer outros takes. Observe uma interpretação intensa e o seu tempo na tela. Suficiente ou curto, justamente para dar vontade de ver mais? Ou é bem longo para o que é dramático se tornar enfadonho? A história é contada de forma linear? Como são as passagens de tempo? Se você conseguir observar algumas dessas coisas, está começando a ver a montagem do filme. Fascinante, não?

Resumo: Neste depoimento, a montadora Mirella Martinelli conta como surgiu o interesse por fazer cinema, ainda na adolescência. Lembra-se dos clássicos que marcaram sua visão de mundo e de toda uma geração, e que fazem parte de sua formação como cineasta. Foi isso que a levou a desejar se expressar através da sucessão de imagens, de cenas, do drama de personagens fictícios. Descobriu que isso tinha uma função específica: a montagem. Mirella nomeia três pontos básicos para o leitor desvendar o trabalho do montador: o que é um plano, o que é uma cena e uma seqüência e, por último, a informação de que um filme não é filmado na sua ordem histórica. Tudo para que o leitor possa compreender o que um montador pode fazer por um filme. Exemplifica o depoimento com trabalhos recentes e conhecidos do público, como Contra todos, Extremo Sul e Terra do mar.

Palavras-chave: montagem, imagens, cinema, produção.

Abstract: In this testimony, editor Mirella Martinelli tells how emerged her interest on cinema still in her adolescence. She remembers classic movies which determined hers and of all her generation vision of world. These movies are part of her formation as a cinematographer and took her to wish to express herself trough images succession, scenes and drama of fictional characters. She found out that there was a specific function for these: film editor. Mirella presents the reader three major points in editor job: what is a plan, what is a scene and a sequence, and, at last, the information that a movie is not shoot in its final order. These pieces of information are important so that the reader should be able to understand editor job in a movie. She illustrates her testimony with examples of three recent and well-known works of her: Contra todos, Extremo Sul and Terra do mar.

Keywords: editor, images, movies, production. 